\title{
Christ and the Principle of Alternative Possibilities
}

\author{
Randall Kenneth Johnson \\ The Southern Baptist Theological Seminary
}

\begin{abstract}
I argue that classical Christology provides reason to reject the categorical reading of the principle of alternative possibilities (PAP). PAP claims that alternative possibilities are necessary for moral responsibility. Classical Christology affirms the doctrine of volitional noncontrariety (VNC) which teaches that Christ's human will could not be contrary to his divine will. The Gethsemane prayer highlights an instance in which Jesus Christ performs a voluntary and morally significant action that he could not have done otherwise, namely, his submission to God's will. First, I present classical Christology and VNC. Second, I define and disambiguate varieties of PAP. Third, I show that Christ's prayer in Gethsemane disproves the categorical reading of PAP.
\end{abstract}

\section{Classical Christology and Volitional Non-Contrariety}

I argue that classical Christology gives us reason to reject the categorical reading of the principle of alternative possibilities (PAP). By 'classical Christology,' I mean the Christology of Scripture and the ecumenical creeds. Classical Christology affirms that Christ is one person subsisting in two natures: human and divine. It also holds to such teachings as the preexistence of the Son, the hypostatic union, the extra-calvinisticum, the communication of attributes, the virgin birth, and the bodily resurrection. ${ }^{1}$ In this section, I highlight that element of classical Christology which leads to the rejection of the categorical reading of PAP: volitional non-contrariety (VNC).

Classical Christology posits two wills in Christ. ${ }^{2}$ As the Chalcedonian logic goes, God the Son is one person in two natures: "our Lord Jesus Christ is one and the same Son, the same perfect in Godhead and the same perfect in manhood, truly God and truly man, the same of a rational soul and body" (Kelly 1978, 339). ${ }^{3}$ Chalcedon was at pains to deny a union of Logos and mere flesh. Rather, the Logos took to himself a complete human nature-body and rational soul. What was implicit at Chalcedon was made explicit at Constantinople III: "And we proclaim equally two natural volitions or wills in him and two natural principles of action which undergo no division, no change, no partition, no confusion, in accordance with the teaching of the holy fathers" (Tanner 1990,128). Thus, dyothelitism is the position of conciliar orthodoxy; Christ has two wills: one human and one divine.

An important distinction must be made between the faculty of the will and the object of the will. Dyothelitism teaches that Christ has two faculties of will (i.e., two natural wills): human and divine. The object of the will, however, is the thing (or state of affairs) willed. This distinction can be seen in Jesus's prayer in Gethsemane in which he resolves to conform the

${ }^{1}$ For the biblical, historical, and systematic theology of classical Christology, begin with Wellum (2016).

2 For expedience, I use the names 'Christ,' 'Jesus,' and 'Son,' interchangeably.

${ }^{3}$ For more on Chalcedonian Christology, see Grillmeier (1975, 543-558).

Journal of Analytic Theology, Vol. 9, Summer 2021 10.12978/jat.2021-9.170007091413

(C) 2021 Randall Kenneth Johnson • (C) 2021 Journal of Analytic Theology 
object of his human will to the object of his divine will: "My Father, if it be possible, let this cup pass from me; nevertheless, not as I will, but as you will" (Matthew 26:39). ${ }^{4}$

Christ's human will could never have been contrary to-but was always in conformity with-the divine will according to its object. ${ }^{5}$ The doctrine of VNC is codified in Constantinople III which reads: "And the two natural wills not in opposition, . . . but his human will following, and not resisting or struggling, rather in fact subject to his divine and all powerful will. For the will of the flesh had to be moved, and yet to be subjected to the divine will ...." (Tanner 1990, 128). That Christ's humanity is subject to his divinity does not entail that Christ's humanity lacked deliberation or even competing desires. ${ }^{6}$ Christ could have competing desires (or objects of the will) as long as (1) the desire upon which Christ acted was conformed to the divine will as to its object, and (2) none of the competing desires were sinful in themselves. ${ }^{7}$ There is a real sense in which Christ did not want to die, but that desire to avoid death was overridden by his greater desire to obey his Father.

\section{The Principle of Alternative Possibilities}

PAP, according to Frankfurt $(1998,1)$, "states that a person is morally responsible for what he has done only if he could have done otherwise." According to PAP, my having said a kind word to my daughter was a moral act only if I could have chosen not to say that kind word to my daughter. Frankfurt himself was critical of PAP, so he produced thought experiments that portended to contradict PAP. Frankfurt-style counterexamples are received with mixed approval. ${ }^{8}$

One difficulty with PAP and the phrase, "could have done otherwise," is that it is ambiguous between a categorical and a conditional reading. Following Bignon (2018), I shall distinguish between $\mathrm{PAP}_{\mathrm{ALL}}$ and PAP $\mathrm{PF}_{\mathrm{IF}}$. Bignon stipulates, "Let PAP ALL be the principle that 'a person is morally responsible for what he has done only if, all things inside and outside the person being just as they are at the moment of choice, he could have done otherwise.' Let us name this sort

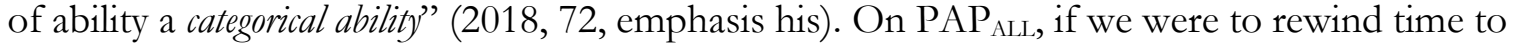
the moment just before I say that kind word to my daughter, with all else being the same, I could have done otherwise.

$\mathrm{PAP}_{\mathrm{IF}}$, according to Bignon, is "the principle that 'a person is morally responsible for what he has done only if he could have done otherwise, had his inner desires inclined bim to do so at the moment of choice" " $\left(2018,72\right.$, emphasis his). This sort of ability is a conditional ability. On PAP $\mathrm{P}_{\mathrm{IF}}$, if we were to rewind time to the moment just before I say that kind word to my daughter, with

4 All Scripture references come from the English Standard Version (ESV). Because wills are natural rather than personal, the Father's will is the very same divine will of the Son.

${ }^{5}$ For biblical support of VNC, consider, for example, John 5:19 and 8:28-29.

6 Theologians of the Middle Ages went to great lengths to show the complexity of Christ's human will in relation to his divine will. Especially noteworthy are Maximus the Confessor and Thomas Aquinas. See Bathrellos (2009) and Barnes (2016) for expositions of Maximus and Aquinas, respectively.

${ }^{7}$ Consider Kane's definition for 'wills': “(W) An agent wills to do something at time t just in case the agent has reasons or motives at $\mathrm{t}$ for doing it that the agent wants to act on more than he or she wants to act on any other reasons (for doing otherwise)" (1998, 30).

${ }^{8}$ The literature on Frankfurt-style counterexamples and PAP is enormous. For a small sample, see Fisher (2011), Haji (2011), and Widerker (2011). 
all else being the same, I could not have done otherwise. But I could have done otherwise, if my beliefs or desires were different at the moment just before the action.

Compatibilists often hold PAP IF to be true and PAP ALL $_{\text {to }}$ be false. ${ }^{9}$ Many incompatibilists, however, hold $\mathrm{PAP}_{\mathrm{ALL}}$ to be true but deny that $\mathrm{PAP}_{\mathrm{IF}}$ is sufficient for moral responsibility. This article is concerned with $\mathrm{PAP}_{\mathrm{ALL}}$, the categorical reading of PAP. The free will literature in contemporary analytic philosophy is full of Frankfurt-style counterexamples. What is missing from the literature is an actual counterexample. If there is an act performed by some agent that is voluntary, morally significant, and one which the agent categorically could not have done otherwise, then PAP ALL is false. I argue, below, that Jesus's resolution to go to the cross, his submission to God's will, exhibited in his prayer at Gethsemane is an actual example of an act that is voluntary, morally significant, and one which he categorically could not have done otherwise.

One further clarification is necessary. Christ is one person subsisting in two natures. The person, Christ, is the one subject of both his human and divine actions-each of which is a principle of action. How PAP relates to Christ's divine freedom is beyond the scope of this paper. Rather, my aim is to show that Christ according to his human nature performed an action that disproves PAP $\mathrm{ALL}^{10}$ The person-nature distinction, therefore, requires us to provide a formula of PAP $\mathrm{ALL}_{\mathrm{L}}$ that fits both persons with one nature and persons with multiple natures:

$\mathrm{PAP}_{\mathrm{N}}$ : a person $P$ is morally responsible for an action only if $P$ could have done otherwise solely via the nature by which $P$ performed that action, all things just as they are at the moment of choice.

$\mathrm{PAP}_{\mathrm{N}}$ is a categorical formulation of $\mathrm{PAP}$ which affirms that natures are principles of action; yet persons, not natures, are moral agents. In what follows, I show that classical Christology provides reason to reject $\mathrm{PAP}_{\mathrm{N}}$.

\section{PAP at Gethsemane}

The Gethsemane prayer has a unique perspicuity on the matter of PAP. Jesus's prayer in the garden is not only a key event in the biblical storyline but also the juncture of multiple christological doctrines and themes. In his prayer, Jesus Christ, the Son of God Incarnate, submits his will to the will of God the Father. Thus, he resolves to volunteer his life- to be put to death for the sins of many: "nevertheless, not as I will, but as you will" (Matthew 26:39). ${ }^{11}$ In this section, I consider Jesus's prayer as a voluntary, morally significant act in light of VNC.

9 Dispositional compatibilists, like Vihvelin (2013), argue that the ability to do otherwise is still necessary for freedom. On this view, I must have those intrinsic properties that underly the power, for example, to say a kind word to my daughter. Because those properties are intrinsic to me, I have the ability to say a kind word to my daughter whether or not I have the opportunity or desire to do so. Christ certainly had the relevant natural (human) powers or dispositions to act otherwise, but natural powers or dispositions do not give Christ the categorical ability to do otherwise.

10 I take Christ's human nature to be concrete rather than abstract. For more on Christ's human nature as concrete, see Hill (2011, 11-12); Crisp (2007, 34-71); and Pawl (2016, 34-39).

11 Compare Mark 14:36 and Luke 22:42. 


\subsection{Christ's Willing Submission}

God sent his Son to save humanity (John 3:16-17). Jesus knew that his mission included his own death; and he knew the time and manner of his death (Matt 16:21; 17:22-23; 20:17-19; 26:2). Indeed, he was commanded to lay down his life willingly and to take it up again: "No one takes it [my life] from me, but I lay it down of my own accord. I have authority to lay it down,

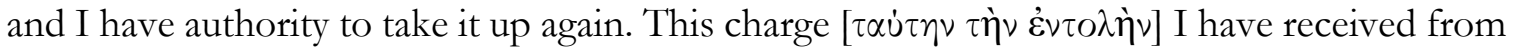
my Father," (John 10:18). Furthermore, the phrase "of my own accord" and the use of the noun "authority" imply both willingness and immunity to coercion or compulsion. ${ }^{12}$ Jesus was commanded to volunteer his life. Because the Father commanded the Son to die- and to die in this way-it would have been a sin, a moral failure, not to volunteer his life.

The narrative leading up to and including Gethsemane indicates that Jesus viewed this moment - this very prayer - as pivotal. In Matthew 26, Jesus foretells his death by crucifixion (v. 2), acknowledges his upcoming burial (v. 12), discloses that Judas will soon betray him (v. 20-25), institutes the Lord's Supper, symbolizing his impending death (v. 26-29), predicts Peter's denial with remarkable accuracy, and tells his disciples to watch and pray as he prays to the Father. Jesus was fully cognizant of what was happening. Jesus's prayer in Gethsemane was his last moment alone with the Father. Would he shirk his mission-run or hide or deny his identity? Or would he submit to the will of God — to be obedient unto death-even death on a cross (Phil 2:8)?

According to VNC, Christ could not have shirked his mission. He had to submit to God's will, and he could not have done otherwise. Yet, this submission was both voluntary and morally praiseworthy. The act's voluntariness is clear from Christ's own words: "I lay it down of my own accord," (John 10:18). The moral significance of this act is supported throughout Scripture. Christ is praised for his obedience (Rom 5:18-19); he is called 'righteous' (Acts 3:14), 'good' (Titus 3:4), 'worthy' (Heb 3:3), and 'faithful' (Heb 2:17). Christ is rewarded for his obedience (Phil 2:9). And we are exhorted to imitate Christ's humility and obedience (Phil 2:511). Christ did the morally right thing: he obeyed God. Therefore, $\mathrm{PAP}_{\mathrm{N}}$ is false. At the moment of choice- his prayer at Gethsemane-Jesus was willing and morally responsible for his action despite not being able to do otherwise. At the moment of Christ's greatest temptation, he willingly submitted to God's will.

\subsection{Objection to Moral Responsibility}

Although I have shown that Christ's submission was a morally relevant act, one might argue that I have merely demonstrated that alternative possibilities are unnecessary in the case of moral praise, but I have not proven anything about moral blame. According to this objection, the conditions for praise and blame are asymmetrical. In order to deem an agent to be morally blameworthy, the agent must have been able to do otherwise. ${ }^{13}$

\footnotetext{
12 Consider Kane's definition of 'voluntary': “(V) An agent acts voluntarily (or willingly) at t just in case, at t, the agent does what he or she wills to do (in the sense of W), for the reasons he or she wills to do it, and the agent's doing it and willing to do it are not the result of coercion or compulsion" $(1998,30)$.

13 Wolf (1990), for example, argues that when moral agents act in accordance with Reason, they are morally praiseworthy even if they could not have done otherwise. But when moral agents are able to act according to Reason but act contrary to Reason, they are morally blameworthy. Therefore, PAP holds in the case of blame but not praise. See also Nelkin (2011).
} 
In response: first, because Christ's human will always concurs with his divine will, there simply are no cases in which Christ deserves moral blame. But, insofar as a morally praiseworthy action is a morally significant action, I have defended my thesis. The Gethsemane prayer is a concrete example in which a person performs a voluntary and morally significant action despite lacking the categorical ability to do otherwise.

Second, the claim that moral praiseworthiness and blameworthiness are asymmetrical is a claim typically made by certain compatibilists, not incompatibilists. Thus, those who make this distinction do not think moral blameworthiness requires the categorical ability to do otherwise, but, rather, it requires some general ability or dispositional capacity to do otherwise. ${ }^{14}$ In this article, I have argued that the categorical ability to do otherwise is not a necessary condition for moral responsibility. I have neither addressed the sufficient conditions for moral responsibility nor proposed a mechanism for free action. Whether any sense of PAP is necessary for moral responsibility is beyond the scope of this article-as is whether the necessary conditions for praise differ from blame.

\subsection{Objection to PAP $_{\mathrm{N}}$}

Although classical Christology provides reason to reject $\mathrm{PAP}_{\mathrm{N}}$, one might deny that $\mathrm{PAP}_{\mathrm{N}}$ is the relevant formulation of PAP $\mathrm{PLL}_{\text {. }}$ Rather, the relevant formulation of $\mathrm{PAP}_{\mathrm{ALL}}$ is PAP.

PAPp: a person $P$ is morally responsible for an action only if $P$ could have done otherwise via the nature by which $P$ performed that action, all things just as they are at the moment of choice.

$\mathrm{PAP}_{\mathrm{P}}$ removes the adverb 'solely' from $\mathrm{PAP}_{\mathrm{N}}$ which results in Christ indeed being able to act otherwise. As the objection goes, the Son qua divinity has the categorical ability to act otherwise; nothing determines or necessitates divine action one way or another. Therefore, according to $\mathrm{PAP}_{\mathrm{P}}$, there is something Christ could have done otherwise than he did: he could have divinely willed that his humanity do otherwise than it did. So, even if Christ could not do otherwise in his humanity simpliciter, the theandric Person could have done otherwise by divinely willing otherwise, thereby changing what he does qua humanity.

I am not convinced, however, that $\mathrm{PAP}_{\mathrm{P}}$ is preferable to $\mathrm{PAP}_{\mathrm{N}}$, and even if it were, classical Christology still provides reason to reject it. Here are three reasons to prefer $\mathrm{PAP}_{\mathrm{N}}$.

First, $\mathrm{PAP}_{\mathrm{N}}$ is preferable to $\mathrm{PAP}_{\mathrm{P}}$ because the question at hand is whether Christ according to his humanity could do otherwise. $\mathrm{PAP}_{\mathrm{N}}$ is able to eliminate all factors outside his humanity; whereas $\mathrm{PAP}_{\mathrm{P}}$ is not. For that reason, it seems more relevant to our own freedom and moral responsibility (and the focus of PAP generally).

Second, PAPp makes the person-nature distinction superfluous with respect to PAP. The ability to do otherwise ought to be found in the same principle of action, the nature, by which the action was performed. The following analogy illustrates this problem with PAP. Suppose my right hand is numb, and my physical therapist asks me if I am able to make a fist with my right hand. If I responded, "Sure, I can. I just need to use my left hand to close my right hand," the physical therapist would not be satisfied with my answer.

\footnotetext{
${ }^{14}$ See McKenna (2013) for a critique of Nelkin's dispositional compatibilism.
} 
Third, the result of $\mathrm{PAP}$ looks suspiciously like a conditional, rather than a categorical result. Christ qua humanity could have willed otherwise only if Christ qua divinity had willed otherwise.

But, for the sake of argument, let us assume $\mathrm{PAP}_{\mathrm{P}}$ is the relevant formulation. The objection, then, can be articulated as such: God the Son could have actualized a world $\left(W_{1}\right)$ exactly similar to the actual world (a) up to the moment of choice $(t)$, but the Son qua humanity did otherwise in $W_{1}$ than in $a$ at $t^{15}$

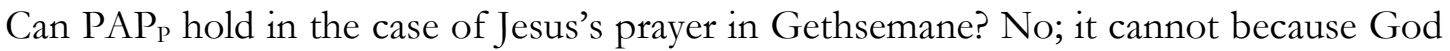
could not have willed his humanity to do otherwise at the moment of choice. First, as shown above, Jesus had certain beliefs about Gethsemane and his impending betrayal and death. He believed this prayer was a pivotal moment in the expression of his obedience-and he believed he would indeed make the ultimate expression of his obedience at that moment. If he were to do other than to submit to God's will, we would have to admit that Jesus held false beliefs about what he, himself, would do.

Second, perhaps we could forbear Christ holding false beliefs qua humanity, but PAPP implies that God is possibly deceptive. Jesus believed he was fulfilling Scripture and God's command and purpose up to the moment of prayer. But if $\mathrm{PAP}_{\mathrm{P}}$ were right, it would be possible for God to deceive Jesus: to lead him to believe certain things about the event in Gethsemane that were not true.

\section{Concluding Thoughts}

I have argued that classical Christology provides reason to reject the categorical reading of PAP. After I reviewed an essential element of classical Christology (VNC) and formulated a version of PAP that accounts for persons with one or more natures $\left(\mathrm{PAP}_{\mathrm{N}}\right)$, I demonstrated that Christ's submission to God at Gethsemane was voluntary, morally significant, and yet, he could not have done otherwise. Therefore, $\mathrm{PAP}_{\mathrm{N}}$ is false.

I have assumed neither determinism nor indeterminism; nor have I tried to explain how Christ's two wills always concur. I have merely shown that alternative possibilities-in the categorical sense-are not necessary for moral responsibility. It remains to be shown whether incompatibilism or compatibilism is true. For example, sourcehood incompatibilists "hold that, although moral responsibility is incompatible with determinism, moral responsibility does not require that the agent could have avoided acting as he did. On this view, what moral responsibility requires is that the agent was the ultimate originator of his act, that is, he performed the act without being in any way caused or nomically determined to perform it" (Widerker 2011, 283). And, of course, compatibilists believe that freedom and moral responsibility are compatible with theological determinism. ${ }^{16}$

\footnotetext{
15 It is not obvious how to interpret "at the moment of choice" in a discussion about God. Is the divine willing occurring at the moment of choice? Or is just the alternative human action occurring at the moment of choice? The answer may depend on God's relation to time. If God is temporal, then the objection might be interpreted in this way: at the moment when Jesus prays in the Garden of Gethsemane, he could have acted via his divine nature to bring about a different response in his humanity than he actually did. But whether God is temporal or atemporal, PAP succumbs to the same criticisms.

16 I am grateful to Timothy Pawl, the participants at the Aquinas and the Crisis of Christology conference hosted by Ave Maria University in 2020, and an anonymous referee for helpful comments on previous drafts.
} 


\section{References}

Barnes, Corey L. 2016. Christ's Two Wills in Scholastic Thought: The Christology of Aquinas and Its Historical Contexts. Pontifical Institute of Mediaeval Studies.

Bathrellos, Demetrios. 2004. The Byzantine Christ: Person, Nature, and Will in the Christology of Saint Maximus the Confessor. Oxford University Press.

Bignon, Guillaume. 2018. Excusing Sinners and Blaming God: A Calvinist Assessment of Determinism, Moral Responsibility, and Divine Involvement in Evil. Pickwick Publications.

Crisp, Oliver D. 2007. Divinity and Humanity: The Incarnation Reconsidered. Cambridge University Press.

Fisher, John Martin. 2011. "Frankfurt-Type Examples and SemiCompatibilism: New Work." In The Oxford Handbook of Free Will: Second Edition, edited by Robert Kane. Oxford University Press.

Frankfurt, Harry G. 1998. "Alternative possibilities and moral responsibility." In The Importance of What We Care About. Cambridge University Press.

Grillmeier, Aloys. 1975. Christ in Christian Tradition Volume 1: From the Apostolic Age to Chalcedon (451). $2^{\text {nd }}$ ed. trans. John Bowden. John Knox Press.

Haji, Ishtiyaque. 2011. “Obligation, Reason, and Frankfurt Examples.” In The Oxford Handbook of Free Will: Second Edition, edited by Robert Kane. Oxford University Press.

Hill, Jonathan. 2011. "Introduction." In The Metaphysics of the Incarnation, edited by Anna Marmodoro and Jonathan Hill. Oxford University Press.

Kane, Robert. 1998. The Significance of Free Will. Oxford University Press.

Kelly, J. N. D. 1978. Early Christian Doctrines, revised ed. HarperSanFrancisco.

McKenna, Michael. 2013. "Source Compatibilism and that Pesky Ability to Do Otherwise: Comments on Dana Nelkin's "Making Sense of Freedom and Responsibility." Philosophical Studies: An International Journal for Philosophy of Analytic Tradition 163.1: 105-116.

Nelkin, Dana Kay. 2011. Making Sense of Freedom and Responsibility. Oxford University Press.

Pawl, Timothy. 2016. In Defense of Conciliar Christology: A Philosophical Essay. Oxford University Press.

Tanner, Norman P. 1990. Decrees of the Ecumenical Councils 2 Volume Set. Georgetown University Press. 
Vihvelin, Kadri. 2013. Causes, Laws, \& Free Will. New York: Oxford University Press.

Wellum, Stephen J. 2016. God the Son Incarnate: The Doctrine of Christ. Crossway.

Widerker, David. 2011. "Frankfurt-Friendly Libertarianism." In The Oxford Handbook of Free Will: Second Edition, edited by Robert Kane. Oxford University Press.

Wolf, Susan. 1990. Freedom within Reason. Oxford University Press. 